\title{
Practicing Civil Religion in Uhuru Kenyatta's First Term Pentecostalized Presidency in Kenya
}

\author{
Bramwel N. Matui \\ Senior Lecturer in Political Science \& Public Administration \\ Moi University \\ Kenya $^{1}$
}

\begin{abstract}
There has been a debate on the presence of civil religion within the United States and it is argument seemed to point to the conclusion that this type of religion serves as a cohesive force in a nation of diverse ethno-national backgrounds. Such a stance posits a question of whether this kind of scenario could be extended to other states that are afflicted by ethnicity and rival ethnic affiliations. In this paper, I examine this concept and explore its applicability to a country like Kenya at a time when President Uhuru Kenyatta and his Deputy William Ruto were publicly active adherents of Pentecostal theology leading to what was dubbed as the Pentocostalization of the presidency. Examining this borderline case using Hart's fourfold criteria of rhetorical contract (guise of separation, guise of equality, appropriate language, and safeguarding contract terms), reveals that civil religion as is conceived in American society-although violated during the Bush Presidency 2001-2009- was practiced in Uhuru's Presidency-implying that it is possible for the leading state politicians to affiliate closely with a sectarian religious theology without violating the ethos of civil religion.
\end{abstract}

Keywords: Civil Religion, Hegemony, Hart's Rhetorical Contract, and political Religion.

\section{Background:}

\section{Uhuru Ruto Presidency (2013-2017) as borderline in Civil Religion}

This article is spurred by a recent study by Stephen Kioko David and Michael T. Katola (2016) entitled The ChurchState Relationship in Kenya after the Second Liberation Struggle. In the study, the Uhuru first term Presidency (20132017) is acclaimed as characterized by "Prayer and Pentocostalization of political life" (2016:52). This implies that the Presidency was a frontier case where the norms of civil religion could be violated as it happened in the United States of America in 2001-2009 when President George Bush embraced evangelical Christianity (Turek 2014:3-4;Curry 2007:1) ${ }^{2}$

The genesis of this attribute of the Uhuru Presidency, according to the authors, is the 2008 Post-Election Violence (PEV), and the indictment of President Uhuru Kenyatta and Deputy President William Ruto in 2010 by the International Criminal Court (ICC) on account of the PEV. The authors further opine that the post-crisis elections of 2013 were conducted in the backdrop of the need to heal the nation from the wounds of the $2008 \mathrm{PEV}$; also to Ruto and Uhuru supporters, the ICC indictment was an act of an evil alliance between some domestic and international political actors to subvert God's will of Uhuru and Ruto ascending to the Presidency. The consequence is that the pair resorted to prayer meetings to beseech God to intervene. To Kioko and Katola, the attractive Christian denomination became Pentecostalism because the denomination gives fervent prayers and prophecies to boot.

Though Uhuru and Ruto (now President and Deputy President respectively) are not members of Pentecostal Churches, they sought to employ Pentecostal ideology to their advantage. Key to Pentecostal theology is the outpouring of the Holy Spirit for salvation, speaking in tongues, miracle working, witnessing, spontaneous singing and prayer, discernment, healing and most importantly deliverance and prophesying (Kioko \& Katola 2016:53).

\footnotetext{
${ }^{1}$ The author was scheduled in the International Institute of Social Studies of Erasmus University to give a public defence of his PhD Thesis entitled "Collective Memory, Interethnic Interactions and the Politics of Becoming and being Sabaot in Kenya."

${ }^{2}$ Turek (2014:!) gives the genesis of president Bush Christian identity and his use of Christian language in his speeches. he notes "over the course of his governorship, he gradually incorporated Christian tropes in his speeches to develop, explain, and gain support for his "compassionate conservative" policies and to build rapport with voters"
} 
The authors opine that prophesy became attractive to both leaders because in their respective communities (Kalenjin and Kikuyu), prophets play a big role in social life for they guide and foretell future events with confidence. The Pentecostal clergy fulfilled this role by speaking of the duo as political servants of God that were unstoppable and who would deliver the Kenyan people to the promised land of healing and development. The rallies that followed thus came to be viewed as politics fusing with Pentecostalism to erase the divide between religion and politics. The two were sworn in March 2013 as President and Deputy President and their victory was viewed as divine victory: the duo knelt when they were being sworn and after that would frequently appear in Pentecostal church services. This analysis by Kioka and Katola begs the question: did the Uhuru Presidency, because of Christianizing their public life, violate the rhetorical contract underpinning civil religion? The rhetorical contract suggests that a President in public life should communicate in a manner that unites the country by avoiding sectarian religious theology. The two authors suggest that the "Jubilee government has been a government of Christianity" (Kioko \& Katola 2016:53). But looking closely at the quotes given to justify this, to me, does not appear to suggest that the divide between religion and state was breached. I will give two quotes beforehand to herald my conviction of this. After being inaugurated, President Uhuru Kenyatta is said to have visited "Kisima cha Nehema Church on Sunday March 10th2013"in which he stated:

I am happy to join you once again today for prayers to thank God for his blessings and for the peace he has given us. Am grateful for your prayers and I have come to fulfill the promise I made during the [political] campaigns that I will be back to give thanks to God when I emerge victorious (Kioko \& Katola 2016:54).

The above quote reveals President Uhuru Kenyatta using the non-denominational title for God. Secondly, President Uhuru uses the collective pronoun "us" to indicate that the pronoun refers to the Kenyan people generally. Thus this speech seems to confirm that Uhuru, in his speech, did fulfill the rhetorical contract of a civil religion. The speech given by Deputy President William Ruto on Sunday March 10, 2013 does not appear to have violated civil religion either for the reasons given for the speech of Uhuru Kenyatta. He was attending church in Faith Evangelistic Ministry in Karen. Ruto said this as tears of joy flowed as he reflected on the victory in election:

I have not cried like this for many years. The only time I remember crying like this was when I was a little boy and my mother is here to attest to that. My wife knew me as a strong man because she had never seen me emotional like this....The same God who gave us victory against all odds will do more exceedingly and abundantly for us. It will be more than the people of Kenya want. God is going to do great things for this country (Kioko\& Katola 2016:55).

This means that in a society of secularized state and non-secularized society (Habermas 2011:22), even when a president is using a sectarian religious organization for instrumental purposes, the President can still be aware of public ethics that require observing the rhetorical contract of the separation of state from religion; this means that a head of state "preaches" a civil sermon that leads to the classification of his/her speech as civil religion. In the foregoing analysis, I have shown that although the President and the Deputy President attended Pentecostal churches for political aims, the two leaders still managed to practice civil religion since in their speeches the non-denominational God is beseeched, and the audience was the plural Kenya rather than the immediate Pentecostal audience.

\section{The Scholarship on Civil Religion}

Recent scholarship has posited that there is a phenomenon called civil religion in the United States of America (Banchoff 2014; Curry 2007). China's renegotiation of Han Confucianism has also been interpreted as an act of the country developing a civil religion to be its global cultural identity brand (Paramore, 2015). The concept of civil religion was part of a counter argument to scholars who posited that the world had become secularized and religion had been jettisoned from the public sphere (Turner 2011: 5; Okon 2013:30). Turner has observed that such a proposition only applied to northern Europe and not the rest of the world. In the rest of the world: Africa, Latin America, Asia and northern America- according to Turner- religion was still a portent force. In fact some thought that scholars should make a difference between government and society and that secularization of government apparatus should not mean secularization of society (Habermas 2011: 23).

Habermas thinks that bracketing off of government from the influence of one religion in society does not mean that religious groups in the wider society are gagged from pursuing their religious beliefs and practices. In the same vein, religious groups as part of civil society are seen as participating with the non-religious in the public sphere; deliberating on the flexing issues of governance and setting the parameters for enactment of the supreme laws of the land, in the making of acts of parliament and other written laws. But perhaps the boldest and the most innovative criticism of the secularization thesis is the proposition that there exists a civil religion in America and China that makes the continuation of religion a political force in the public sphere. The main argument for the need of civil religion in a country is that it acts as a cohesive force (a hegemonic force) in a nation of diverse ethno-national backgrounds. 
Philip S. Gorski (2008) in an article Civil Religion Today posits that civil religion in America acts like a glue that holds the state together even in cut-throat political contests in contemporary America; it provides a restraining base that prevents politics from getting degraded into extreme egoism and which therefore can count as a disciplinary power facilitating the winner to celebrate and the looser to congratulate the winner. To Gorski where civil religion has been weak in America, this has hurt public interest as seen in political stalemates that has affected the operations of government.

It is an American scholar Robert Bellah in 1967 who stirred the debate by claiming that a civil religion existed in America and this could be seen as a type of generic religion that unified the diverse American people. There are two sources of civil religion in America: Old Testament Theology of the covenant people and the Civic Republican virtues Gorski 2008:4; Bailyn 1992). Covenant with God was an important theology of the New England Puritans who performed a ritual of fidelity to the covenant with God, before departing to the New Land, establishing new towns or new churches (Gorski 2008:4). Classical Civic Republicanism as the second source of civil religion in America, posit that to be free is to be without servitude of any kind including dysfunctional behaviours; it also argued that civic virtues in society protect society from destructive tendencies (Gorski 2008:5).Both Covenant Theology and Civic Republicanism share the tradition of freedom in life, that society should be based on moral foundations; in the same vein, both warn of cyclical kind of social life where vile can lead to virtue and virtuous behavior can degenerate to the phase of vice filled society (Gorski 2008:5-6). Civil religion promotes the view of society where state and religion is separate, but politics is seen as constituted by religion, and citizens in their diversity are encouraged to deploy "religioethical argumentation" to justify their actions and judgment (Gorski 2008:10).

Kiri Paramore (2015: 274) in his article, Civil Religion and Confucianism: Japan's past China's Present and the current boom in Confucianism has provided a view that civil religion arises out of social struggles in society. While discussing secularist ideology- a national morality- seen as equivalent to civil religion in mid twentieth century Japan. Paramore argues that this national morality was a product of hegemonic articulation that included state Shinto, various strands of Buddhism, Catholicism, among other religions and state structures which interfaced to develop the national morality of this country. Paramore thus concludes that the national morality was not imposed on society by the state but was rather a sociological phenomenon. Paramore argues further that in this country, the school and the army saw a budding secularist ideology brand of nationalist morality that was advocated by the leading public academician Inoue Testujiro (1855-1944). The non-religious strand of national morality was constructed to contrast Christianity which also vied to influence the school curriculum in Japan (Paramore 2015: 274). Inoue clothed Shinto religion ${ }^{3}$ in nonReligious/ secular clothing as something that rhymes with natural sciences (as contrasted with Christianity and Buddhism) in order to hedge it as a national/ public morality that was unifying rather than fragmenting to the Japanese society (Paramore 2015: 274). In this way, Confucianism was deployed in twentieth century Japan as something that is analogous to civil religion (Paramore 2015: 275).

Roderick Hart in his Article The political Pulpit (1977) provides the means of empirically verifying if civil religion exists by furnishing the criteria for evaluating if there is balance between political power and the religious in the rhetoric of a political leader. Thus Hart treats a President's public speech as a performative act or a ritual that hail the collective identity of the state rather than sampling the sectarian theology of a religious group. The criteria for this separation are: guise of separation, guise of equality, appropriate language, and safeguarding contract terms (Curry 2007: 32- 38). Guise of separation principle posits that state and religious actors when they acts should keep their identities and their societal mission as separate. The guise of equality requires that both the state and religion be treated in the rhetoric as equals; both can talk about public policy but the religious should just stop at rhetoric, while the government does the actual work of implementing public policy. ${ }^{4}$ Thirdly, appropriate language requires that "the religious should not be too political and the political should not be too religious" (Curry 2007:36). Fourthly, safeguarding contract terms means that any of the parties should not talk about specific co-operation in a particular area between the two actors.

Another relevant concept in this study is Michael Foucault's Pastoral power discussed in the Subject and Power (Foucault 1982:213 Curry 2007:25) where state power is seen as a type of a new pastoral power that is enacted on the population. Foucault differentiates between the old pastoral power which operates in the Christian religions and the new one that acts in the realm of the state. In order to understand if a political leader acts to offset the balance between the state and the religious, it is prudent to differentiate this old and new pastoral power.

\footnotetext{
${ }^{3}$ This is Japanese Confucianism

${ }^{4}$ The government should do this without co-opting religious groups in the Government's work 
The old pastoral power has the following three attributes (Curry 2007:24): 1): the power seeks salvation of an individual in the new earth; 2) it is a dualistic kind of power that commands the flock but at the same time can "sacrifice itself for the lives and salvation of the flock" ; 3 ) it is the exercise of power over both the collectivity and the individual in his or her life course;4) the exercise of power requires knowledge ability of subjects in an in-depth and more intrusive manner so as to monitor the lives for improvement and compliance. The new pastoral power, on the other hand, has the following three attributes (Curry 2007:25-26): 1) salvation is defined in this earthly concerns like achievement of health, education, infrastructure and other concerns ; 2) the exercise of this power entailed an increase in the number of personnel be it within the state apparatus itself or by way of private ventures, welfare societies, benefactors and by philanthropists rather than by religious organizations" ; 3) knowledge revolved around the community and the individual.

Among others, hegemony as a concept is important in this study. Laclau Ernesto and Chantal Mouffe (2001) in their book Hegemony and Socialist Strategy opine that hegemony is a type of symbolic unity that is articulated amongst people with diverse identities; the individual identities overflow their boundaries to merge and be merged by others so that there is an overlap in political subjectivity to yield all-encompassing symbolic identity (Laclau \& Mouffe 2001:1112). ${ }^{5}$ An important view of hegemony relevant in this study is the one formulated by Antonio Gramsci. Gramsci moved away from the political leadership basis of hegemony to "the intellectual and moral plane" which shifts the articulating/the uniting force in society from economic or class leadership to leadership based on the "ensemble of ideas and values" (Laclau \& Mouffe2001:66-76). On the role of religion in articulating various interests, Gramsci admires the Catholic Church for:

"...ability to maintain continuity and social cohesion among the disparate social groups, given that it is able to contain and unify the practical operation of the 'religion of the people' (or the 'simple') and the religion of the intellectuals" (Green 2013:11). ${ }^{6}$

Thomas Banchoff (2014:2), although not using the concept "articulating hegemony", argues that the American civil religion refer to "core political values and national narratives embedded in state institutions, articulated across the political spectrum, and linked back to the country's dominant religious traditions."'Thus a hegemonic agent builds unity in society through promotion of ideas and cultural values that are meant to knit together societies or sections of communities that have divergent interests and world views. Civil religion, as a neutral theology, should be conceptualized as a hegemonic value system, and the political leader- in a diverse nation-state engaged on it- should therefore be carrying out hegemonic articulation to build nationhood.

\section{Problem Statement and Research Objectives}

Kenya is a multi-ethnic and multi-racial state where the question of cohesiveness is a topical issue. The state also has a liberal constitution and this implies that the state is secular, although as already explained, the Kenyan society like the United States is not secularized; rather society is highly religious as the Uhuru first term Presidency (2013-2017) has revealed. This study is guided by the following research questions:-

1. What is the social economic and political context, which influenced the practice of civil religion in Uhuru's first term Presidency?

2. How do the speeches by Uhuru Kenyatta reflect Hart's 4 rhetorical contract of civil religion?

\section{Theory and Methodology}

This study used purpose sampling of two speeches given by Uhuru Kenyatta as President of the Republic of Kenya. These speeches given in annex 1are: 1) Speech 11 given during the Prayer Breakfast on 25th May 2017; and 2) the speech he gave Commemorating KDF Day on $14^{\text {th }}$ October 2014. I use the theory of hegemonic articulation in my analysis as a way of viewing the President's speech as an attempt to enact the Kenyan state as a space of political hegemony that knits together the diversity of Kenya to create a unifying national consciousness. The specific criteria of evaluating this diversity are Hart's fourfold criteria of rhetorical contract: guise of separation, guise of equality, appropriate language, and safeguarding contract terms.

\footnotetext{
${ }^{5}$ This act of overlapping in political subjectivities is what the authors refer to as symbolic over-determination.

${ }^{6}$ But Gramsci viewed this articulation of disparate groups in Italy as a negative thing for religious common sense did not bequeath the masses with liberating political disposition. 


\section{Context of Civil Religion in Kenya: Two Conflicting Memories of Kenya}

Kenya's civil religion appears to be a product of synthesis of two conflicting past memories that have characterized narration about Kenya: Kenya as an exceptional yet imperfect state- a narrative reflected in President Kenyatta's speech as presented at the end of this section. To me it appears the content of Kenya's civil religion portrays a nation in a quest for a national morality. Yet the interesting revelation is that both the exceptionality and the imperfection of the Kenyan state are conjoined memories that can be traced to the era of colonial rule.

The notion of Kenya's exceptionality can be traced to colonial memories of Kenyan highlands' unique attributes of near temperate climate and yet astride the Equator. Indeed the first such observation was made by Joseph Thomson who, while in a travel from the coast of Tanzania to Mumias in western Kenya in 1889, marveled at the beauty of the Kenyan vegetation in Uasin Gishu plateau (Thomson 1897: 94-97; Murunga 1998: 94). It is such reports by Thomson that led some parts of Kenya to be declared white highlands, an area that the white settlers were willing to turn into enclaves of white settlement. In fact Githae-Muge captures such first memories of Kenya by white settlers which involved isolating the pristine beauty of the land with the "savagery" of the natives. Githae-Muge (1978: 13-17) argues that Mrs Espheth Huxley who wrote both fictitious works (The Flame Trees Of Thika and On The Edge Of The Rift) and the non-fictitious works (White Man's Country and A New Earth) about Kenya, memorialized Kenya as rich in wild game with a pleasant climate but weak in the human element. Mrs. Huxley in these fictitious and non-fictitious works, views Africans as lower than whites in mental capacities, were lazy, and superstitious. This dualism in colonial thinking was replicated in the design of land in colonial days: a large swathe of land, from Nairobi to Mt Elgon that had cool climate, was declared white highlands (Ward \& White 1971: 99). The rest of the land was designated as native reserves. The large scale appropriation of the white highlands from around 1910 had by the late 1920s led to shortage of land amongst the natives who appealed to the colonial government to consider allocating them land (Ward \& White 1971: 121). But the European settlers in their defense argued- even with the contrary evidence- that when they took over land, the land was Terra nullius implying empty (ArapNg'eny 1970: 122-123; Lam 2004: 138). Some others argued that it was good to dispossess the native Africans and keep the white highlands in the hands of European settlers because the settlers were bearers of civilization and productive force to help the Kenya colony be self-reliant (Huxley 1935: V; Colony \& Protectorate of Kenya 1933: 2102-2107; Ward \& White 1971: 99).

Africanist scholars view Kenya's modern ills as a product of colonial policies of indirect rule that was characterized by neo-patrimonial relations that was cascaded to the lower levels through African chiefs (Mamdani 1996: 25-27;Berman 1998: 316; Kilingray 2010: 40). The African chiefs were given autonomy to exercise power and could reward those they considered family members, ethnic folks, or friendly; on the converse, African chiefs could discriminate those they considered different(Berman 1998: 317). As already mentioned the colonial government privileged European access to land and marginalized Africans (Materu 2015: 17-21). Additionally, from 1920s right up to 1950s, colonialists only supported African participation of politics at the local level and the space at the national level was frozen (Ochieng 1975: 164). What this implies is that African politicians and scholars have blamed the weakness of the Kenyan state on the colonial policies of divide and rule and the predatory state that managed to continue in the post-independence state as elite impunity, ethnicity and corruption.

In technocratic terms, the selfsame duality in perception of the Kenyan state exists with Kenya seen as exceptional on account of its capitalist market system, stable political system, the origin of mankind and entrepreneurial spirit. Professor Peter Kagwanja, the CEO of African Institute in a recent Daily Nation in March 2019 (Kagwanja 2019) depicted Kenya as a "regional model in the capitalist periphery." To Kagwanja, Kenya's adoption of capitalism, and its experience of a stable political system, and an exemplary 2010 liberal democratic constitution, has made the country the "City in the Hill" in a tumultuous capitalist periphery. The Magical Kenya brand has also been bolstered by the archeological narratives in which east Africa and Kenya in particular has been praised as the origin of Homo Habilisand Homo Erectus (Lahr \& Foley 2016; Kenya Tourism board n.d). But Kenyan exceptionalism has increasingly been seen through the prism of human element and talent. Foremost, Kenya has become famed for middle and long distance global athletes that have possibly made Kenya one of the most visible African countries globally (Turner, Santos \& Onywera 2014;Wilber \& Pitsiladis 2012). Secondly, Kenya in Africa has been famed as a country that is rich in human resources and entrepreneurial spirit, for, Kenyan owned companies are becoming the norm in eastern Africa and are spreading to the rest of Africa (Ngugi 2016). Related to the foregoing is innovation in ICT related products, especially money transfer Mpesa, which has made Kenya one of the foremost countries in financial mobility and financial transactions (Munda 2018; The East African 2015). 
Finally Kenya's diaspora in the West have succeeded as professionals and some political roles a case being President Obama whose father was Kenyan to create a more hopeful Kenyan nation as exceptionally endowed in human talent (Wesonga2018; Parsons 2015). ${ }^{7}$

But despite this more positive memorialization of the country that circulates in the public sphere, the other negative side of Kenya is equally a subject of discourse with negative ethnicity, impunity, and corruption taking the lion share of blame. Professor Kagwanja (2019) bemoaned the negative intrusions like high level corruption, negative ethnicity and poor political leadership that was soiling the Kenyan brand. This duality of the Kenyan state is constitutive of the practice of "sermons" of civil religion in Kenya. For example Uhuru Kenyatta stated explicitly about this duality of Kenya in the process lambasting those that seek to emphasize one memory of the two. In a Speech during the Prayer Breakfast on $201725^{\text {th }}$ May 2017(see speech 1 in annex A) the President stated:

And so it is with those who are ungrateful: they can see what is wrong about Kenya, and they mistake it for the whole. There is an opposite error. There are those who see what is right about Kenya, and they too mistake it for the whole. Let us admit, ladies and gentlemen, that we have sometimes fallen short of God's law. Kenya still has difficulties with corruption. We still have difficulties with leadership. We are still divided among ourselves; we are still divided by religion, by ethnicity, by gender, and by region. These divisions are not of our own making; they are problems we have inherited.

\section{Rhetorical contract and Civil Religion during Uhuru first term Presidency}

By civil religion I mean discourses about the transcendental that uses neutral language that unifies all the religious actors in the public sphere. The 2010 Kenyan constitution in its preamble starts by stating "We, the people of Kenyaacknowledging the supremacy of the Almighty God of all creation" (Republic of Kenya 2010: Preamble). The constitution mentions God in a generic manner so that Muslims, Christians, and others that have a supreme being can identify with. In such a case, the constitution enacts the transcendental in a manner that unites people that have competing traditions about the transcendental. This kind of practice in nation states are imperatives of unity to facilitate political parties that can mobilise across religious lines, and generally to enact state identity and loyalty as a crosscutting identity. Thus civil religion is an element of identification with statehood in order to bestow a state with divine origin and therefore social legitimacy. Divine legitimation of the state, it appears, is done because life within the state has a certain level of unpredictability: the state is exposed to war, natural calamities and other challenges where the transcendental need to be appealed to be watchful to the state. Habermas captures such a view:

"Religion" owes its legitimizing force to the fact that it draws its power to convince from its own roots. It is rooted, independently of politics, in notions of salvation and calamity and in corresponding practices of coping with redemptive and menacing forces. (Habermas 2011:17).

Thus although the Kenyan constitution is based on democratic self-rule, the legitimizing role of the divine is extinguished (Habermas 2011:21); the religious nature of society suggest that the divine accomplishes his will through the rule bound democratic processes of electoral campaigns and universal suffrage. The implication of the foregoing is that a space where the generic transcendental is mentioned is a ritual space that fosters cohesion and loyalty to the nation. This can be seen in Heroes Day usually celebrated on 22 October each year, and other holidays, including national prayer day, and days, of memorials of Kenya Defence Forces that passed on in the course of duty.

Prayer Breakfast Meetings: Annual prayer breakfast meetings in the contemporary Kenyan are spaces where politics and religion fuse and the president's rhetorical contract between the state and religion can be evaluated. The annual breakfast meeting in Kenya started in 2002 after President Kibaki romped into power upon President Daniel Moi's retirement after ruling for 24 years. President Dwight Eisenhower, a devout Jehovah witness by faith, and President from 1953-1961- a time of tumult for the American state, is famed to have founded the breakfast prayer meeting tradition in America (Curry 2007:65). This practice of breakfast prayer meetings has become established in other countries. For example, protestant religious leaders, educated in American seminary colleges, inaugurated Korea National Prayer Breakfast in 1966; in the prayer services, the Korean dictatorial rulers that took power a military coup and ruled between 1962-1967- and who were invited to attended the meetings- were preached to and beseeched to convert to Protestantism and espouse protestant ideals of liberty, equality, and fraternity as the basis of establishing a legitimate politics and national morality (Yoo \& Kim 2018:5). The Annual breakfast meetings in Kenya were occasioned by the triumph of second liberation marked by Mwai Emilio Kibaki winning the Presidency in 2002.

\footnotetext{
${ }^{7}$ Parsons Reported that while president Obama, was in a visit in Kenya in july 2015 he referred to himself as "Kenyan-
} American" 
This win by Kibaki was also seen as the win by the faith based groups agitating for a greater democratic space in Moi's Presidency between 1985-2002 (Kioko \& Katola 2016: 45). The win by Kibaki led to celebrations that included faith based organizations starting faith based annual prayer meetings. In these celebrations, religious leaders were given large part of the proceedings. These celebrations and ceremonies took the form of prayer breakfast meetings, which marked the early period of Kibaki's Presidency (Kioko \& Katola 2016: 48).

President Uhuru attended some of this breakfast prayer meetings organized by The Kenya Parliamentary Prayer Fellowship Group and Parliament of Kenya to bring the country leadership together to pray and unite the Nation. On 25th May 2017 at Safari Park Hotel, he noted that "Some of you in the audience today will remember the very first Prayer Breakfast I attended, shortly after I took office." This quote suggests that President Uhuru Kenyatta did not attend every annual prayer breakfast. In what follows, I evaluate President Uhuru's speech based on the four criteria discussed by Hart (1977): The criteria for this separation are: guise of separation, guise of equality, appropriate language, safeguarding contract terms. As for guise of separation between religion and state, the President appears ware of this separation when he recognizes the religious group as the other by stating:

"Second, we have a duty of gratitude to the generations that came before us: the generations that fought for independence, the campaigners for democracy in the 90s; the thousands upon thousands of public servants who keep us safe; and the Churches, temples and mosques which have been such important teachers of moral truth throughout our history"

In the third line of the above speech, President Uhuru mentions different religious groups as the builders of Kenya's moral norms and values. He does not privilege one religion; in the same vein, he implies that the state is not the same thing as a religious group. The above lines, in attributing the moral and spiritual fabric to religious organizations, also suggest that President Uhuru Kenyatta fulfilled the rhetorical contract on the recognition of equality of state and religion in their respective spheres. The President talked about salvation in this world in terms of socio-economic development, in the following sectors: education. Health, transport and governance as matters that the Kenyan people have achieved as "God's blessings." Although the President mentions God's blessings, it is clear that he attributes the acts of success to Kenyans operating as a free people in an independent state. On appropriateness of language, the language in the speech is religious in tone but not a sectarian theology, it is a civil language. Although President Uhuru cites three versus from the Bible: Psalms 136:26, Ephesians 2:8, and Psalm 133:1, it is clear that his intention is to use the word God in a non-denominational manner. In the three versus, he talks of God of heaven" as the one that has bestowed blessings on the Kenyan nation. The use of "blessing" here is not in reference to salvation in the other world but salvation in this world in the four areas mentioned in this speech: education, health, transport and governance. The lines on diversity quotes the holy Qur'an injuncting human beings to embrace diversity as a positive thing, is probably a strong use of religious register to preach a civil sermon of religious and ethnic tolerance in the country. As he comes to the conclusion of his speech President Uhuru Kenyatta alludes to the co-operation between the state and religious groups in fostering good governance in Kenya. He states:

...we in government have made every preparation for a free and fair election. But you know, as well as I do, that this is a matter not just for government but for every Kenyan - and, most especially, for all of Kenya's leaders, not least among them her spiritual leaders. By and large the leaders of our churches and mosques and temples have kept Kenyans and their leaders on the straight and narrow path. I ask you, once again, to play that role. Pray for us; and pray for the country. Preach peace; and teach us to love God and our country ever more intensely. Thank you. God bless you all.

In this portion of speech, the president fulfills the fourth criterion of the spiritual contract- safeguarding contract terms. Here although the President is explicit that free and fair elections are the co-operation of the state and religion, he did not divulge the contract terms. He just mentions the cooperation between the two institutions of society in general terms. Thus president Uluru's speech can qualify as a civil sermon and not as a sectarian theological Sermon. Next, I examine the President's speech on Kenya Defence Force (KDF) day on $14^{\text {th }}$ October 2014.

\section{Kenya Defence Force (KDF) day on $14^{\text {th }}$ October 2014.}

The KDF day was established to commemorate the sacrifice of Kenya Defence forces including honouring those that passed on in the course of duty. Thus each year, the President has an opportunity to attend this event where prayers by the clergy are an important accompaniment.

The somber mood makes the event more religious and the President's speech is meant to have religious overtones. But like the Annual Breakfast speech analyzed above the President's Speech was a civil sermon rather than an exposition of sectarian religious theology. My position is reached following analyzing the speech using Hart's fourfold criteria: guise of separation, guise of equality, appropriate language, safeguarding contract terms. The President recognizes the 
separation of state from religion when he states "Unlike the terrorists, we believe in the sanctity of human life; in the dignity of all people, whatever their religion; and in the cohesion of our different communities." In another related line, the President opines "the wide variety of men and women who serve in the KDF- from different regions, and communities, and faiths - shows clearly that you are a living symbol of our national unity." In these two quoted lines, the President takes the state as an identity that binds people from different religions; to an extent that KDF is taken as an exemplary mirror of unity in diversity that Kenya aspires to be. The President's speech also implies a guise of equality in the sense that nowhere does the President indicate that safeguarding the country should be left to religious actors; instead he reiterates that role as the act fulfilled by the heroic acts of the KDF personnel. The third attribute is appropriate language where the President's speech is not overly religious. In fact the speech mentions God only at the end of the speech and he mentions him as a non-denominational God. He states:-

Let me now close by once again expressing my personal grief, and the nation's deep sorrow, at the loss of all those patriotic Kenyans who have fallen in the line of duty. May God grant their souls eternal peace. We will always honour their memory, and we will always strive to live up to the values for which they gave their lives.

The quote, apart from "May God grant their souls eternal peace" which is a signature way of bringing to an end the transcendental civil sermons, in the next lines, transit to what the people in this world should do to the departed. He says the living will memorialize them and emulate their heroic acts of defending their country. Thus the President steers a clear course from the old pastoral speech of personal salvation in heaven.

\section{Conclusion}

This article has revealed that political leaders that exhibit close affinity with sectarian religious ideology can still practice civil religion. President Uhuru Kenyatta was able to do this through the act of bracketing himself off from sectarian theology which he left to the clergy. When he spoke, he was conscious of himself as a "state priest" rather than the priest of a sectarian theology. It appears that President Uhuru Kenyatta, to attain that goal of bracketing himself off from sectarian religious theology, carried out self-evaluation. Self-evaluation has been said to be a tool of keeping one's positive face through carrying out self-identity verification that fits with one's role in changing circumstances(Stets \& Burke 2003:6). This position finds resonance with Alexandre Lefebvre's recent article The End of a Line: Care of the Self in Modern Political Thought (2016:14); Lefebre opined that the juridical subject is able to take care of self through self-monitoring where he/she could question, restrain or modify his/her actions to rhyme with the requirements of the law and the needs of the wider society. ${ }^{8}$ Thus although President Uhuru Kenyatta would attend Pentecostal Christian services and events presided by Pentecostal clergy, as the Head of State that had taken an oath to protect the Kenyan constitution, Kenyatta was able to affirm constitutional order in his speeches. ${ }^{9}$

\section{References}

Arap Ngeny, Samwel K. (1970). "Nandi Resistance to the Establishment to the British Administration 1893-1906." In Bethwell A. Ogot (Ed.) Hadith 2: Proceedings of the 1968 Conference of the Historical Association of Kenya (104-126). Nairobi: The East African Publishing House

Bailyn, B. (1992). The Ideological Origins of the American Revolution. Cambridge: Harvard University Press

Banchoff Thomas(2014)."American Civil Religion, Foreign Policy, and the Challenge of Multipolarity."Prepared for International Workshop on The Impact of National Cultures on Foreign Policymaking in a Multipolar World," Berlin, October 3-4, 2014.

Berman Bruce(1998)."Ethnicity, Patronage and the African State: The Politics of Uncivil Nationalism."African Affairs, Vol. 97, No. 388 (Jul., 1998), pp. 305-341. Oxford University Press

Colony \& Protectorate of Kenya (1933).Kenya Land Commission. Evidence Vol. II. London: Colonial Office, Kenya.

Curry E, Christina (2007). Civil Religion and Pastoral Power in the George W. Bush Presidency. A Master of Arts Thesis in the College of Arts and Sciences Georgia State University

Foucault, Michel (1982). "The Subject and Power."Michel Foucault: Beyond Structuralism and Hermeneutics. Ed.Hubert L. Dreyfus and Paul Rainbow. Chicago: The University of Chicago Press, 208-226.

Githae-Mugo, Micere (1978) Visions of Africa: The Fiction of Chinua Achebe, Margaret Laurence, Elspeth Huxley \& Ngugi wa Thiong'o. Nairobi: Kenya Literature Bureau.

\footnotetext{
${ }^{8}$ Levebre in this article was trying to critique Michael Foucault's idea that modern political thought, characterized by the juridical subject/ the subject of law, is unable to pursue the care of self. Levebre on the contrary states that law can be an instrument to monitor and manage self.

${ }^{9}$ The Kenyan constitution has clauses implicit of the presence of civil religion.

85
} 
Gorski Philip S.(2008). Civil Religion of Today. The ARDA: Association of Religion Data Archives.

Green Marcus E.(2013). Race, Class and Religion: Gramsci's concept of Subaltermity. The political Philosophies of Antonio Gramsci and B.R. Ambedkar: Itineraries of Dalitsand Subalterns (CosimoZeneed.) New York: Routledge pp.116-128.

Habermas Jorgen (2011). The political: The Rational Meaning of a Questionable Inheritance of Political Theology. In the Power of Religion in the Public Sphere pp.15-33: Judith Butler,Jürgen Habermas, Charles Taylor \& Cornel West (eds.) Thepower of Religion In the Public Sphere. New York: Columbia University Press.

Hart, Roderick P.(1977).The Political Pulpit. West Lafayette: The Purdue University Press.

Huxley, E. (1935) White Man's Country. 1st edition. London: Chatto \& Windus

KagwanjaPeter (2019). How Corruption is Sinking the 'Kenya model' and Uhuru Legacy. The Sunday Nation 20 March 2019. Nairobi: Nation Media Group. Accessed on 14 July 2019 at:

https://www.nation.co.ke/oped/opinion/How-corruption-is-sinking-Uhuru-legacy/440808-501700411 wougn/index.html

Kenya Tourism Board (n.d). Kenya Truly the Cradle of Mankind. Accessed on 14 July 2019 at :http://www.kenyabrussels.com/ckfinder/userfiles/files/about\%20Kenya/tourist\%20brochures/Cradle_of_Man kind.pdf

Killingray, David (2010) Fighting for Britain. African Soldiers in the Second World War. Suffock: James Currey.

Lam, Marvan Clech (2004) "Remembering the Country of their Birth: Indigenous Peoples and Territoriality." Journal of International Affairs, 57(2): 129-149.

Laclau Ernesto \& Chantal Mouffe (2001). Hegemony and socialist Strategy: Towards a Radical Democratic Politics. Second edition. London: Verso

LahirMarta Mirazon\& Robert Foley (2016).Chapter 12 Human Evolution in Late Quaternary Eastern Africa, pp.215231.https://www.researchgate.net/publication/301232255_Human_Evolution_in_Late_Quaternary_Eastern_Af rica/link/59e33487aca2724cbfe36a63/download

Lefebvre Alexander. 2016). The End of a Line: Care of the Self in Modern Political Thought Genealogy 2017, 1, 2 pp.1-14

Mamdani, Mahmood (1996) Citizen and Subject: Contemporary Africa and the Legacy of Late Colonialism: New Jersey: Princeton University Press.

Materu, S.F. (2015) The Post-Election Violence in Kenya. The Hague: T.M.C. Asser Press.

Meng Meng (2012). Chinese Soft power: the Role of Culture and Confucianism. A Capstone Project Submitted in Partial Fulfilment of the Requirements of the Renée Crown University Honors Program at Syracuse University

Murunga, M. Godwin (1998). The Evolution of Mumias Settlement into an Urban Centre to Circa 1940 (Master's Thesis, Faculty of Arts, Kenyatta University).

Munda Constant (2018). Kenya firms up innovation Hub Status with Sh14bn deals. Business Daily July 19, 2018 10:26. Nation Media Group. Accessed on 14 July 2019 at https://www.businessdailyafrica.com/economy/Kenya-firms-up-innovation-hub-status/3946234-4670880$8 \mathrm{n} 7 \mathrm{pk} 1 /$ index.html

Ngugi Brian (2019). Kenya overtakes SA as biggest investor in African countries. Daily Nation July 29 2016. Nairobi: nation media group. Accessed on 14 July 2019 at: https://www.nation.co.ke/business/Kenya-overtakes-SA-asbiggest-investor-in-African-countries/996-3320992-y8eciaz/index.html

Ochieng, William R. (1975).The First Word: Essays on Kenyan History. Nairobi: East African Literature Bureau.

Okon Etim E. (2013).Critical Re-examination of Sociological Theories of Religion. Asian Journal of Social Sciences \&Humanities vol. 2 no2 pp 22-36

Paramore Kiri (2015) “Civil religion and Confucianism: Japan's past China's Present and the current boom in Confucianism'The Journal of Asian Studies / Volume 74 / Issue 02 / May 2015, pp 269 - 282

Parsons Christi (2015). Obama, calling himself 'Kenyan American,' urges African nation to embrace progress.Los Angeles times July 26 25. Accessed on 19 July 2019 at: https://www.latimes.com/world/africa/la-fg-obamaurges-kenyans-to-part-with-old-ways-20150726-story.html

Republic of Kenya (2010).Constitution of Kenya, 2010.Nairobi: National Council for Law Reporting with the Authority of the Attorney-General.

Ronning Helge (2014). "How much Soft power does China have in Africa?" Paper Presented at the International Conference China and Africa Media, Communications and Public Diplomacy 10 - 11 September 2014 Beijing

Stets Jan E.and Peter J. Burke (2003). A Sociological Approach to Self and Identity. Chapter for Handbook of Self and Identity, edited by Mark Leary and June Tangney, Guilford Press

The East African Standard (2015). Kenya tops list of banked population due to high mobile money uptake .April 25 2015. Nairobi: nation media group. Accessed on 19 July 2019 at: 
https://www.theeastafrican.co.ke/business/Kenya-tops-list-of-banked-population/2560-2697138jh9o4iz/index.html

Thomson J. B.(1897). Joseph Thomson, African Explorer : a Biography by his brother, (J.B. Thomson) ; with contributions by friends. London : Samson Low, Marston

Tucker Ross, Jordan Santos \& Vincent Onywera (2014). Analysis of the Kenyan Distance-Running Phenomenon. International journal of sports physiology and performance · August 2014 10, 285-291. https://www.researchgate.net/publication/264745551_Analysis_of_the_Kenyan_Distance-

Running_Phenomenon/link/550fcb9e0cf2ac2905af1cfa/download

Turek Francis Lauren (2014).Religious Rhetoric and the Evolution of George W.Bush's Political Philosophy.Trinity UniversityDigital Commons. Accessed on 19 July at:

https://digitalcommons.trinity.edu/cgi/viewcontent.cgi?article=1024\&context=hist_faculty

Turner Bryan S. (2013).Religion and contemporary sociological theories. Sociopedia.isa

Ward, E.F. \& White W. (1971) East Africa: A Century of Change 1870-1970. London: George Allen \& Unwin Ltd.

Wesonga Charles (2018). Kenyans ranked 3rd most hardworking foreigners in US. Daily Nation August 212018. Nairobi: nation media group. Accessed on 14 July 2019 at: https://www.nation.co.ke/news/diaspora/Kenyans ranked-3rd-most-hardworking-foreigners-in-US/2107720-4722054-109n1tx/index.html

Wilber Randall L. And Yannis P. Pitsiladis (2012). Kenyan and Ethiopian Distance Runners: What Makes Them So Good? International Journal of Sports Physiology and Performance, 2012, 7, 92-102. Accessed on https://www.researchgate.net/publication/225064362_Kenyan_and_Ethiopian_Distance_Runners

What_Makes_Them_So_Good/link/54abb5f90cf2bce6aa1d9b69/download

Yoo Yohan \& Minah Kim (2018). "Korea National Prayer Breakfast" and Protestant Leaders' Prophetic Consciousness during the Period of Military Dictatorship (1962-1987) Religions 2018, 9, 308; doi:10.3390/rel9100308

\section{ANNEX A: SPEECHES of UHURU JENYATTA}

1. Speech 1L Prayer Breakfast 2017 25th May 2017. ${ }^{10}$

Good morning, ladies and gentlemen: What a pleasure it is to see you today; and what a pleasure it is to join you for this year's prayer breakfast. Some of you in the audience today will remember the very first Prayer Breakfast I attended, shortly after I took office. Today, I return to the theme I sounded then: gratitude. Psalm 136: 26 requires it of us:”... to give thanks to the God of heaven, for his steadfast love endures forever". Now, this year's breakfast falls at a good time. In a few days, we will celebrate Madaraka; we will celebrate fifty-four years of self-government. It is easy to take our self-rule for granted. It is even easier to forget two things: the sacrifices our fathers made to win that self-government for us, and the grace of God, which has brought us through half a century of struggle and triumph. Look around you. This country has more schools, more hospitals, than our fathers could ever have dreamed of. Kenyans live longer than the generation which celebrated the first Madaraka day. Fewer of our mothers die in childbirth. Many more of our elders live in dignity - a fitting reward for their years of labour. Many more of our children are in school; and many more of them attain the highest international standards. It is much easier to get around the country now than it was, even a few years ago — and, in a few days, it will be even easier, when we officially commission the first phase of the SGR. These are achievements, but we also know that all our achievements are, in the end, God's blessings. For although God does not bless those who don't work, even those who do work should remember the words of Ephesians 2:8: "this is not your own doing; it is the gift of God". So, there is much to be thankful for. I repeat the words with which I began: "We give thanks to the God of heaven, for his steadfast love endures forever". God loves this country; God has blessed this country. We owe him our praise and thanks. I say so - I emphasize the point - for two reasons. First, there are some of us who have forgotten the duty of gratitude. Second, there are some of us who are complacent. Let me take them in turn. Some of us can only see what is wrong with Kenya, not what is right. Regrettable, but all too true. They cannot see the advances we have made, nor will they give thanks for the achievements that God's guidance has made possible. Today, I want to reach out to them, and to remind then of our duty of gratitude. We ought, first and foremost, to thank God, for the distance he has brought us. Second, we have a duty of gratitude to the generations that came before us: the generations that fought for independence, the campaigners for democracy in the 90s; the thousands upon thousands of public servants who keep us safe; and the Churches, temples and

10 http://www.president.go.ke/2017/05/25/speech-by-his-excellency-hon-uhuru-kenyatta-c-g-h-president-of-the-republic-ofkenya-and-commander-in-chief-of-the-defence-forces-during-the-national-prayer-breakfast-at-safari-park-hotel-nairobi/

Speech by his Excellency hon. Uhuru Kenyatta, C.G.H., President of the Republic of Kenya and Commander in Chief of the Defence Forces during the National Prayer Breakfast at Safari Park Hotel, Nairobi, 25th may 2017. 
mosques which have been such important teachers of moral truth throughout our history. From my vantage point as your President, I have come to a new appreciation of the power of example - and never more so than the example of the church - in the guidance of Kenya's affairs. When I was younger, I sometimes heard it said that an error was a truth pushed too far. And so it is with those who are ungrateful: they can see what is wrong about Kenya, and they mistake it for the whole. There is an opposite error. There are those who see what is right about Kenya, and they too mistake it for the whole. Let us admit, ladies and gentlemen, that we have sometimes fallen short of God's law. Kenya still has difficulties with corruption. We still have difficulties with leadership. We are still divided among ourselves; we are still divided by religion, by ethnicity, by gender, and by region. These divisions are not of our own making; they are problems we have inherited. But even though they are not of our own making, they are most certainly ours to solve. And solve them we will. The first step is prayer: I hold in my mind the words of Psalm 133:1: "How good and pleasant it is when God's people live together in unity!" The second step is to recognise that our diversity is part of God's plan. I was reminded of this by a beautiful verse in the Qur'an, recently pointed out to me: "O Mankind: We created you from a male and a female; and made you into tribes and nations that you may get to know each other". There is nothing wrong with our diversity; but our goal must be unity. Of course, this is not the place for detailed examination of the work of my government, and other Kenyans of goodwill, such as yourselves, to protect and defend our unity. Rather, our purpose today is to consider the broad principles, which govern that unity, and to see whether we have lived up to them. If we haven't, then fraternal correction is in order; where we have lived up to them, fraternal congratulation is appropriate. We will have more to say to each other about this today, and in the weeks to come. Today, I want to close my remarks with a word or two on the elections. We thank God for the opportunity to choose our leaders freely. It is a very precious gift. But we cannot take gifts for granted. That is why we in government have made every preparation for a free and fair election. But you know, as well as I do, that this is a matter not just for government but for every Kenyan - and, most especially, for all of Kenya's leaders, not least among them her spiritual leaders. By and large the leaders of our churches and mosques and temples have kept Kenyans and their leaders on the straight and narrow path. I ask you, once again, to play that role. Pray for us; and pray for the country. Preach peace; and teach us to love God and our country ever more intensely. Thank you. God bless you all.

\section{2: Speech Commemorating KDF Day $14^{\text {th }}$ October $2014^{11}$}

Distinguished Guests,

Ladies and Gentlemen,

It is a pleasure and a privilege to be with you today. I say a privilege because this day is set aside to recognize and to honour our gallant officers, men and women of the Kenya Defence Forces, who have devoted their lives to defending this nation.

Today, we also remember those who lost their lives in various military operations, including international peacekeeping missions, all over the world. There is no greater honour than to share this solemn commemoration with you.

Ladies and Gentlemen,

Kenya's men and women in uniform have always inspired a sense of dedication to duty, pride and professionalism in their rank and file. They have also inspired the nation.

In an age when many military forces in Africa - indeed, in many other parts of the developing world -sank into fruitless politicking, the Kenya Armed forces remained professional, steadfast and loyal to the Government of the day.

The Kenya Defence Forces, born after the promulgation of our new constitution, continues to build on the high standards of professionalism and discipline that its predecessor upheld. That is why it has already become the efficient, modern and patriotic organization that Kenyans are rightly proud of.

Ladies and Gentlemen,

Today, Kenyans join you in honouring those among you whose lives were given in the defence of this nation. We commemorate our fallen heroes in the knowledge that although they are departed, their spirit lives on with us, and in each one of us. Their example lights the way for us, and reassures us that we too are capable of the feats they achieved. As we remember them, let us not forget that defending our nation and region has never been harder than it is today.

We live in an age of potent transnational threats to our security. Severe challenges still trouble our nation and region - among them the evil work of terror networks from around the globe. These terrorists still target unarmed civilians, hoping to create fear in our hearts, and to divide and sow hatred among us. But broadly speaking, we as a nation have, when it matters most, shown a sense of unity and therefore avoided falling into the whims of thieves and murderers. This has been the basis for our success so far.

Part of that resilience is owed to the KDF, whose diligence in protecting the nation and the region from terrorists has been outstanding. Let me commend your exceptional conduct of "Operation Linda Nchi", which culminated in the liberation of Kismayu from the Al Shabaab terrorists, and which has been rewarded with other significant advances in recent months.

\footnotetext{
${ }^{11}$ Speech by h. E. Hon. Uhuru Kenyatta, C.G.H., President andCommander in chief of the Defence Forces of the Republic of Kenya during the KDF day at 3 Kenya Rifles, Lanet, 14th October 2014.
} 
Ladies and Gentlemen,

These experiences - the heroic toil of our young men and women in uniform - should not be lost to us, or to our children. That is why I am grateful that the book we have just launched today will be read for generations to come. I have nothing but praise for the KDF for choosing to document, for the first time in our history, their experiences in war.

Let the experiences stir you to rededicate yourselves to the noble calling of protecting your country and promoting peace in our region. Let this work be guided by our common values. Unlike the terrorists, we believe in the sanctity of human life; in the dignity of all people, whatever their religion; and in the cohesion of our different communities.

Even as I say this, it is not lost on me that the wide variety of men and women who serve in the KDF - from different regions, and communities, and faiths - shows clearly that you are a living symbol of our national unity. It is that cohesiveness which earned the KDF the recognition, at the recent Nairobi International Trade Fair, of the Top Award in national cohesion and integration.

Ladies and Gentlemen,

As strong as the KDF has been in our national Defence, the fact of the matter is that security is a shared responsibility. We must all share with the KDF the burden of defending our territorial integrity, and the lives and property of our people. Each of us must do what we can, with our neighbours, and with the authorities, to protect the nation that we love, and to secure it for all of us, and for those who live with us.

Ladies and Gentlemen,

Let me now close by once again expressing my personal grief, and the nation's deep sorrow, at the loss of all those patriotic Kenyans who have fallen in the line of duty. May God grant their souls eternal peace. We will always honour their memory, and we will always strive to live up to the values for which they gave their lives.

Asanteni.Munguawabarikinaawalindewalinziwetu 